\title{
Formation of insulin-positive cells in implants of human pancreatic duct cell preparations from young donors
}

\author{
M. Bogdani ${ }^{1}$, V. Lefebvre ${ }^{1}$, N. Buelens ${ }^{1}$, T. Bock ${ }^{2}$, M. Pipeleers-Marichal ${ }^{1}$, P. In't Veld ${ }^{1}$, D. Pipeleers ${ }^{1}$ \\ ${ }^{1}$ Diabetes Research Center, Brussels Free University (VUB) and JDRF Center for Beta Cell Therapy in Europe, Brussels, Belgium \\ ${ }^{2}$ Research Laboratory for Stereology and Neuroscience, H:S Bispebjerg Hospital, University Hospital of Copenhagen, Denmark
}

\begin{abstract}
Aims/hypothesis. Pancreatic ducts are considered as potential sites for neogenesis of beta cells. In vitro studies have reported formation of islets from postnatal human and rodent duct tissue. We examined whether postnatal human duct-cell preparations can generate new beta cells after transplantation.

Methods. Pancreatic duct cells were prepared from the non-endocrine fraction of human donor pancreases that were processed for islet-cell isolation. Grafts containing 0.5 million duct cells with $1 \%$ contaminating insulin-positive cells were implanted under the kidney capsule of normoglycaemic nude mice. At 0.5 and 10 weeks post-transplantation, implants were examined for their cellular composition and for the volumes of their composing cell populations, i.e. cytokeratin 19-positive duct cells, synaptophysin-, insulin- and glucagon-positive endocrine cells.

Results. Between week 0.5 and 10, duct-cell volume decreased by at least $90 \%$ whereas the change in insulin-positive cell volume depended on donor age. Im-
\end{abstract}

plants from donors over10 years had a threefold decrease in their insulin-positive cell volume, while those from donors under 10 years had a 2.5 -fold increase. After 10 weeks, the implants from the younger donors consisted of $19 \%$ insulin-positive cells occurring as single units or small cell clusters. Three percent of these insulin-positive cells also expressed the ductal marker CK 19 and were consistently found in conjunction with ductal epithelia; up to $1 \%$ was positive for the proliferation marker BrdU and located in small endocrine cell clusters.

Conclusions/interpretation. These data indicate that duct cell preparations from donors under 10 years can generate insulin-positive cells. This process might involve differentiation of CK 19-positive-insulin cells that are formed at the duct epithelia as well as proliferation of insulin-positive cells within endocrine cell aggregates. [Diabetologia (2003) 46:830-838]

Keywords Human pancreatic duct cells, transplantation, neoformation, beta cell.
Received: 6 December 2002 / Revised: 26 February 2003

Published online: 28 May 2003

(C) Springer-Verlag 2003

Corresponding author: D. Pipeleers MD PhD, Diabetes Research Center, Brussels Free University (VUB) and JDRF Center for Beta Cell Therapy in Europe, Laarbeeklaan 103, Brussels, 1090 Belgium

E-mail: Daniel.Pipeleers@vub.ac.be

Abbreviations: SYN, synaptophysin; INS, insulin; BrdU, bromodeoxyuridine; GLUC, glucagon; PBS, phosphate-buffered saline; CK 19, cytokeratin 19.
Throughout life, the size of the pancreatic beta-cell mass depends on the rates of beta-cell neogenesis and death. New beta cells might be formed by differentiation from stem cells or precursor cells $[1,2,3,4]$, by transdifferentiation of other pancreatic cell types $[5,6$, $7,8,9]$ or by replication of beta cells $[10,11,12]$. These processes could occur within or outside the islets of Langerhans. Since several decades, the pancreatic ducts have been considered as sites where new beta cells are formed $[13,14,15]$. Supporting evidence has been collected from different models but is largely indirect $[16,17]$. In a more recent study, adult human duct tissue was cultured over 3 to 4 weeks and 
it generated islet-like structures which increased the insulin content of the preparations [18]. The mechanisms underlying formation of beta cells from duct cells as well as its relevance in vivo are still unclear. It has been proposed that addition of an extracellular matrix and selected agents might induce differentiation of duct cells to islet cells [18]. It is important to know whether a similar process can occur in human islet grafts which are known to be heavily contaminated by pancreatic duct cells [19, 20, 21]. To investigate this possibility we prepared human pancreatic duct cells $[22,23]$ and followed their cellular composition and cell population volumes over 10 weeks after transplantation in nude mice.

\section{Material and methods}

Preparation of human pancreatic duct cells. Human donor pancreata were procured by transplantation teams associated with the Eurotransplant Foundation (Leiden) or with the Surgical Hospital at Helsinki University (Dr. K. Salmela). They were processed by the Beta Cell Bank in Brussels with the purpose of preparing islet-cell grafts for a clinical trial in diabetic patients. During this procedure, the endocrine-enriched fraction is separated from exocrine-enriched fractions. The latter were further processed to a duct-cell enriched fraction wherein cytokeratin-19 was used as a duct-cell marker [22, 23]. We used duct-cell preparations from 14 donors of age 1 to 63 years. The steps of the isolation procedure were similar to those described previously $[19,20]$ as were the culture conditions [22, 23]. Briefly, after collagenase digestion of the pancreas and Ficoll gradient centrifugation, the residual cell fraction that remained after islet isolation was harvested, washed and cultured in suspension for $7 \pm 3$ days (mean \pm SD) at $37^{\circ} \mathrm{C}$ in Ham's F10 medium (BioWhittaker, Md., USA) containing $0.5 \%$ bovine serum albumin. As this cell fraction is rich in CK19-positive cells (80\%, Table 1) it is referred to as duct-cell fraction.

Transplantation. Eight-week-old male $\mathrm{Nu} / \mathrm{Nu}$ Balb/C BYJIco nude mice were purchased from IFFA Credo (Brussels, Belgium). The mice were kept under aseptic conditions and had free access to pelleted food and water. All procedures were conducted according to protocols and guidelines approved by the Ethics Committee of the Brussels Free University (VUB). Animals were anaesthetized with an intraperitoneal injection of avertin (2.2.2 tribromoethanol, $500 \mathrm{mg} / \mathrm{kg}$ body weight, Aldrich, Wis., USA) and the kidney was exposed by an incision in the flank. Duct cell aggregates were aspirated into a polyethylene tubing, spun down and injected under the kidney capsule. Animals were killed either 0.5 or 10 weeks after transplantation. One hour before the animals were killed, they were injected intraperitoneally with $50 \mathrm{mg} / \mathrm{kg}$ body weight of 5-bromo 2'deoxyuridine (BrdU, Sigma, St. Louis, Mo., USA). They were killed by cervical dislocation and the graft-bearing kidneys were processed for histology.

Immunohistochemistry. Samples of the initial graft and of the implant-bearing kidneys were fixed in $4 \%$ neutral phosphate buffered formalin and embedded in paraffin. The entire graft was serially sectioned at a mean section thickness of $5 \mu \mathrm{m}$. Sections were incubated overnight at $4{ }^{\circ} \mathrm{C}$ with the following primary antibodies: mouse anti CK 19 (1:20; Dako, Denmark),
Table 1. Cellular composition of human ductal cell grafts before, and 0.5 or 10 weeks after transplantation into nude mice

\begin{tabular}{lccc}
\hline Immunostain & Graft at start & Week 0.5 & Week 10 \\
\hline Chymotrypsin & $18 \pm 18$ & $5 \pm 6^{\mathrm{a}}$ & $0^{\mathrm{b}, \mathrm{c}}$ \\
CK 19 & $79 \pm 18$ & $93 \pm 6^{\mathrm{d}}$ & $84 \pm 15$ \\
Synaptophysin & $1.5 \pm 1.3$ & $1.1 \pm 1.4$ & $17 \pm 18^{\mathrm{e}, \mathrm{f}}$ \\
Insulin & $0.9 \pm 0.7$ & $0.8 \pm 1.0$ & $11 \pm 11^{\mathrm{e}, \mathrm{f}}$ \\
Glucagon & $0.5 \pm 0.4$ & $0.2 \pm 0.3$ & $3 \pm 3 \mathrm{~g}, \mathrm{f}$ \\
\hline
\end{tabular}

Results are presented as the means \pm SD of the percentage of immunopositive cells

Statistically significant change in the mean cellular composition in:

${ }^{\mathrm{a}} p=0.005 ;{ }^{\mathrm{d}} p=0.002: 0.5$-week-old graft versus graft at start

$\mathrm{b} p=0.001 ;{ }^{\mathrm{e}} p=0.001 ;{ }^{\mathrm{g}} p=0.002: 10$-week-old graft versus graft at start

${ }^{\mathrm{c}} p=0.001 ;{ }^{\mathrm{f}} p=0.001: 10$-week- versus 0.5 -week-old graft

rabbit anti synaptophysin (1:20; Dako), guinea pig anti insulin $(1: 5,000)$ and rabbit anti glucagon $(1: 5,000)$ (both a gift from Dr. C. Van Schravendijk-Brussels Free University-VUB), rabbit anti somatostatin (1:5,000, prepared by Dr. J. de Mey when at VUB), rabbit anti pancreatic polypeptide (1:50,000, gift of Dr. R.E. Chance, Lilly Res. Lab. Indianapolis, Ind., USA) or anti-chymotrypsin (1:5,000, gift of Dr. G. Kloppel, University of Kiel, Germany). Since synaptophysin is a marker for neuroendocrine cells [24], it allows a comparison of total endocrine and total duct-cell volumes; it can also indicate the appearance, if they exist, of other endocrine cells than those classically identified in adult islets. Sections were washed in phosphate-buffered saline (PBS, $0.1 \mathrm{mmol}, \mathrm{pH}$ 7.4) and incubated with a peroxidase labelled anti mouse (1/20, Amersham, UK), anti rabbit (1/20, Amersham, UK) or anti guinea pig (1:100, Cappel, Aurora, Ohio) secondary antibody for $30 \mathrm{~min}$ at room temperature. The peroxidase reaction was developed by incubation in $0.3 \% \mathrm{H}_{2} \mathrm{O}_{2}$ and $0.15 \% 3.3^{\prime}$ diaminobenzidine tetrachloride (Sigma, St. Louis, Mo., USA). For CK 19-insulin double labelling, FITC-labelled anti-guinea pig Ig and Cy3labelled anti mouse Ig secondary antibodies (The Jackson Immunoresearch Laboratories, West Groove, Pa., USA) were used. Positive and negative controls were included in each staining experiment. To determine the proliferation index of the CK19-positive or endocrine cells, sections were double stained for BrdU (1:20, Cappel, Aurora, Ohio) and each of the following markers: CK 19, synaptophysin, insulin or glucagon. The proliferation index is expressed as the percentage of cells co-staining for BrdU and the specific marker over the total number of cells in the section staining for this marker. Countings included at least 2,000 cells per animal for BrdU analysis and 1,000 cells for determining cell composition.

Stereologic analysis. Stereologic analysis of the grafts was based on Cavalieri's principle: the total volume of CK19-positive (CK 19), synaptophysin-positive (SYN) and insulin-positive (INS) cells was estimated using a point-counting method [25]. Each graft was entirely sectioned at $5 \mu \mathrm{m}$ section thickness. Every fortieth section was immunostained for one of the three markers and stereologically examined using a light microscope (Leica DMLB, Leica, Denmark) equipped with a projecting arm (Leica) to project the image onto the table.

To estimate the total CK 19-cell volume, a 140-point grid was randomly superimposed onto CK19-stained sections at a final magnification of 305×. For each graft 200-700 points hitting CK 19 cells were counted. To estimate the total endocrine 

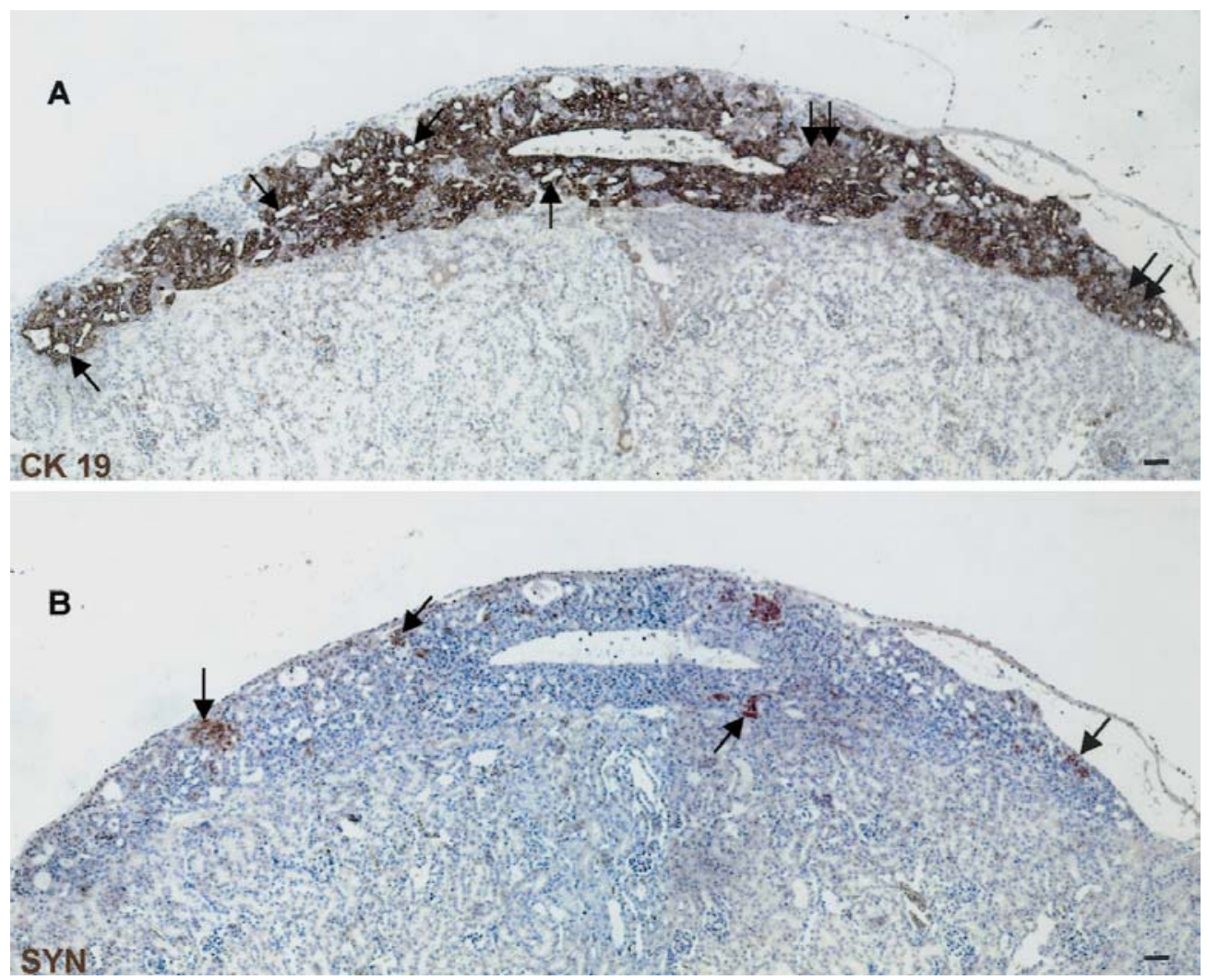

Fig. 1A, B. Human duct-cell grafts transplanted into nude mice kidney stained for the duct cell marker CK 19 (A) and the (neuro) endocrine marker synaptophysin $(\mathbf{B})$. In all grafts removed 0.5 week after transplantation, CK 19-positive cells were oriented around openings (arrows), forming duct-like structures or were organized in cell clusters (double arrows) (A). Endocrine cells were much less frequent and were observed scattered between the CK19-positive cells either as single cells or small clusters (arrows) (B).The scale bar represents $50 \mu \mathrm{m}$

and beta-cell volume, a 600-point grid was superimposed on synaptophysin or insulin-stained sections at a final magnification of $610 \times$. For each graft $200-700$ points hitting the immunopositive cells were counted. In the grafts of older donors, removed 10 weeks after transplantation, the low number of $\mathrm{CK}$ 19 , synaptophysin and insulin-positive cells only permitted the evaluation of 70 to 150 points. The total volume of immunepositive cells was calculated by multiplying the total number of points overlying the immune-positive cells per section with the area per point $\left(4283 \mu^{2}\right.$ for a 140 -point grid and $301 \mu \mathrm{m}^{2}$ for a 600-point grid) and the distance between subsequent immunostained sections $(200 \mu \mathrm{m})$.

We measured the "mean beta-cell area" by dividing the total beta-cell area in the sections by the number of beta-cell nuclei. Although not an unbiased estimator of cell volume, this parameter can be used as a rough indicator of changes in the mean beta-cell volume [26].

Statistical analyses. Significance of the change in total cell volume and percentage of immunopositive cells at 10 weeks versus 0.5 week post-transplant was evaluated using the Wilcoxon Signed Ranks test. Significance of the change in total cell volume and percentage of immunopositive cells in 0.5 -week-old or ten-week-old grafts of the donors younger than 10 years compared with the donors older than 10 years was evaluated using the Mann-Whitney test. A $p$ value of less than 0.05 was considered statistically significant.

\section{Results}

Cellular composition of implants. The ductal cell graft removed 0.5 week after transplantation was visible under the kidney capsule as a white spot, up to $2 \mathrm{~mm}$ in length and width. It consisted predominantly of cells that stained positive for the duct-cell marker CK $19(93 \pm 6 \%$ of the cells, mean \pm SD) (Table 1, Fig. 1A). More than $80 \%$ of these CK 19 cells were bordering lumina (Fig. 2A). The percentage of chymotrypsinpositive $(\mathrm{CHYM})$ cells $(5 \pm 7 \%)$ was lower than in the initial graft $(18 \pm 18 \%, p=0.005)$; they occurred as small compact clusters between CK 19-positive epithelia. SYN-cells were present at the same low percentage $(1 \pm 1 \%$-Table 1$)$ as at implantation; they occurred as single units ( $46 \%$ of all SYN cells) or as small cell clusters (less than ten cells in a section); larger islet-like cell clusters were virtually absent (Fig. 2B). SYN cells were scattered throughout the graft and were surrounded by CK 19 cells (Fig. 1B); they mainly corresponded to INS cells (Table 1).

Ten weeks after transplantation, grafts were consistently smaller than after 0.5 week. They were still mainly composed of CK 19 cells $(84 \pm 15 \%$, Table 1$)$. CHYM cells were absent, while the percent of SYN cells was more than tenfold higher than at implantation time or at 0.5 week after transplantation 


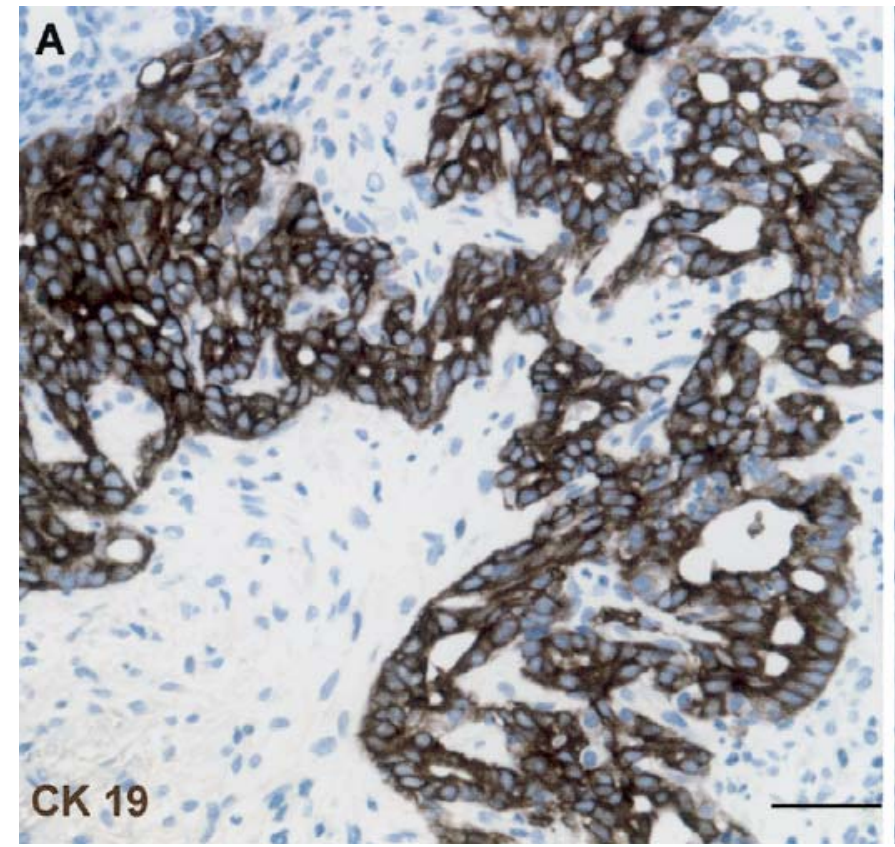

Fig. 2A, B. Immunostaining for the duct cell marker CK 19 (A) and the (neuro) endocrine marker synaptophysin (B) in a graft from a 2-year-old donor removed 0.5 week after trans-

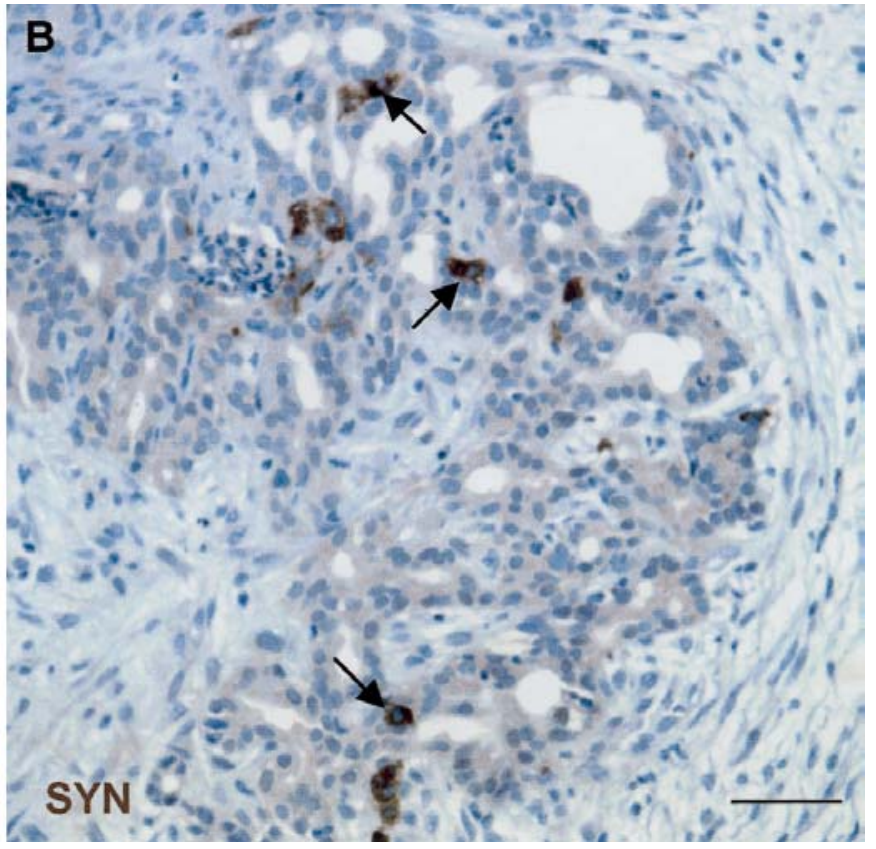

plantation. The endocrine cells (arrows) are observed mixed with the duct cells or located at the periphery of the aggregates. The scale bar represents $50 \mu \mathrm{m}$

Table 2. Total volume and percentage of cells staining for CK 19 or Synaptophysin in implants 0.5 and 10 weeks after transplantation

\begin{tabular}{|c|c|c|c|c|c|}
\hline \multirow[t]{2}{*}{ Cell population } & \multicolumn{2}{|l|}{ Week 0.5} & \multicolumn{2}{|l|}{ Week 10} & \multirow{2}{*}{$\begin{array}{l}\% \text { week } 10 \\
\text { vs week } 0.5\end{array}$} \\
\hline & volume & relative $\%$ & volume & relative $\%$ & \\
\hline \multicolumn{6}{|c|}{ ALL DONORS $(n=14)$} \\
\hline CK 19+SYN & $340 \pm 211$ & & $34 \pm 58^{\mathrm{a}}$ & & $9 \pm 11$ \\
\hline CK 19 & $336 \pm 206$ & $93 \pm 6$ & $26 \pm 41^{a}$ & $84 \pm 15$ & $6 \pm 6$ \\
\hline CK 19+SYN & $402 \pm 297$ & & $64 \pm 80^{c, ~ B ~}$ & $15 \pm 14^{\mathrm{E}}$ & \\
\hline CK 19 & $394 \pm 290$ & $96 \pm 2$ & $45 \pm 58^{c}, C$ & $74 \pm 16$ & $10 \pm 7^{\mathrm{F}}$ \\
\hline SYN & $8 \pm 8^{A}$ & $2 \pm 2^{\mathrm{D}}$ & $20 \pm 25 \mathrm{D}$ & $26 \pm 16^{\mathrm{D}}$ & $332 \pm 383^{G}$ \\
\hline \multicolumn{6}{|c|}{ DONORS $>10 y(n=8)$} \\
\hline CK 19+SYN & $293 \pm 116$ & & $12 \pm 14^{\mathrm{a}}$ & & $3 \pm 4$ \\
\hline
\end{tabular}

Total volume is expressed in cubic micromet-re $\left(10^{-6}\right)$. Values represent mean \pm SD of the total cell volume and the percentage of immunopositive cells.

The small letters indicate a statistically significant change in the mean total cell volume or mean cellular composition in 10 weeks vs 0.5 -week-old grafts $\left({ }^{\mathrm{a}} p=0.012 ;{ }^{\mathrm{b}} p=0.005 ;{ }^{\mathrm{c}} p=0.028\right.$; d $p=0.001)$.

(Table 1). The SYN cells again mainly corresponded to INS cells (Table 1). The ratio of INS or GLU cells over SYN cells was similar in 0.5- and 10-week-old grafts, with the INS cells accounting for $66 \pm 9 \%$ and $68 \pm 9 \%$ of the endocrine cell population in 0.5 and 10 -week-old grafts.
The big letters indicate a statistically significant difference in the mean or the change in total cell volume and mean cellular composition in 0.5 -week-old or 10-weeks-old grafts of the donors younger than 10 years versus the donors older than 10 years (A, $p=0.003 ; \mathrm{B}, p=0.029 ; \mathrm{C}, p=0.043 ; \mathrm{D}, p=0.001 ; \mathrm{E}, p=0.008$; $\mathrm{F}, p=0.0013 ; \mathrm{G}, p=0.002)$.

The $p$-values higher than 0.05 are not noted in the table

Volume measurements of implanted cell populations. In 10-week implants the donor-cell volume, as expressed by the sum of the volume of CK 19 cells plus that of SYN cells, was tenfold lower than in 0.5 week implants (Table 2). This decrease was the result of a massive reduction in the total volume of CK 19 cells 
Table 3. Total insulin cell volume and percentage of insulin, glucagon and synaptophysin positive cells in implants at 0.5 and 10 weeks after transplantation

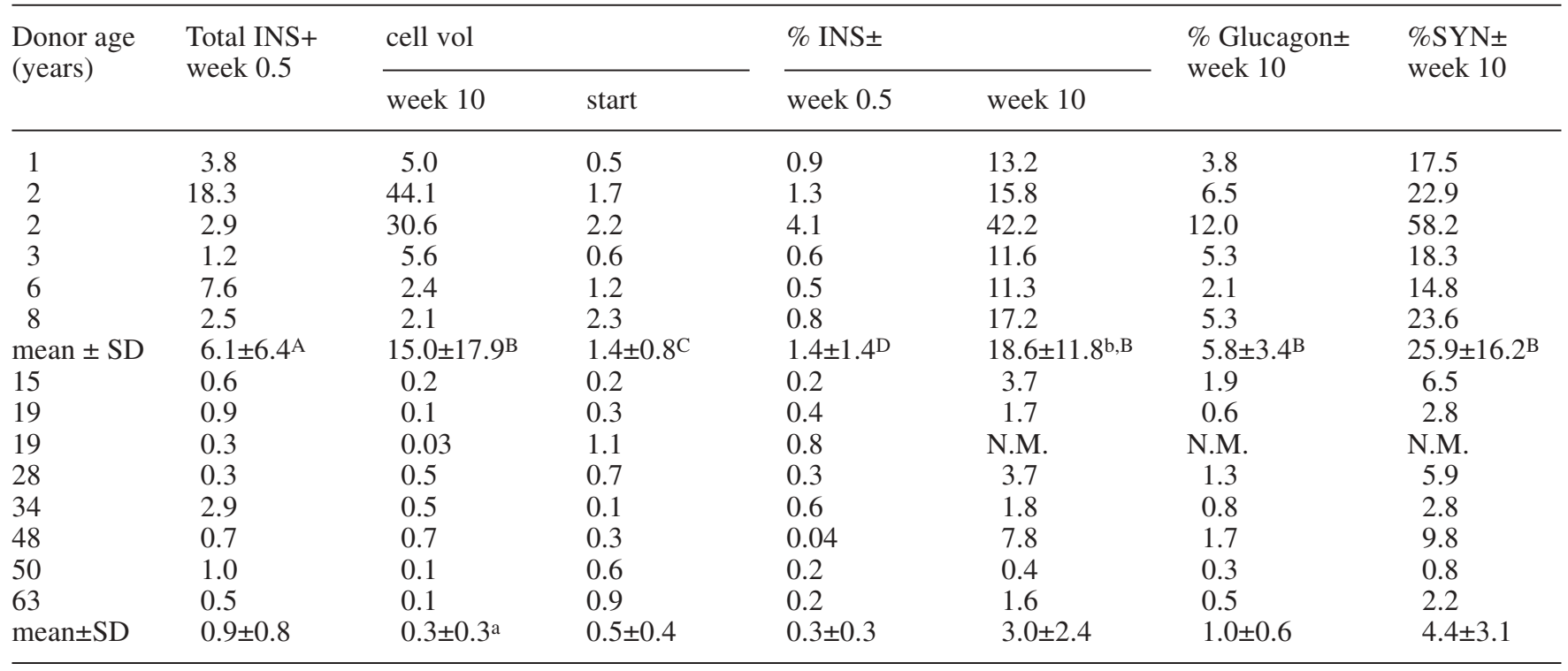

Total volume is expressed in cubic micrometre $\left(10^{-6}\right)$.

The small letters indicate a statistically significant change in the mean total beta-cell volume in:

( ${ }^{\mathrm{a}} p=0.025 ; \mathrm{b} p=0.028 ; 10$ weeks versus 0.5 -week-old grafts)

The big letters indicate a statistically significant difference in the mean total beta-cell volume or mean cellular composition in 0.5 -week or 10 -weeks-old grafts of the donors younger than 10 years versus the donors older than 10 years $(\mathrm{A}, p=0.003 ; \mathrm{B}$, $p=0.001 ; \mathrm{C}, p=0.029 ; \mathrm{D}, p=0.008)$.

The $p$-values higher than 0.05 are not noted in the table.

N.M., not measurable

higher in 0.5 week implants from young donors $(p=0.003$, Table 3$)$. This trend to higher values after 0.5 week might indicate the start of a process that ultimately leads to higher values after 10 weeks. We can not assess this possibility since no measurements were carried out immediately after transplantation.

Characteristics of 10-week duct-cell implants from young donors. Duct cell grafts from donors younger than 10 years resulted in 10-week implants with $19 \%$ INS cells which is 13-fold higher than at the start or at week 0.5 (Table 3). The 10-week implants from older donors contained 3\% INS cells for a total INS cell volume that amounted to only $2 \%$ of that from young donors (Table 3). Similar differences were seen in the percentage of the SYN cells-which was consistently higher as this population contained also other endocrine cells, in particular glucagon-positive cells (Table 3). Sixty percent of SYN and INS cells occurred as clusters of three or more cells many of which were closely associated with CK 19 cell bordered sacs or ductules while some were surrounded by interstitial tissue (Fig. 3A). Single or coupled SYN and INS cells were often located within the wall of these sacs or ductules, adjacent and peripheral to the CK 19-positive border (Fig. 3B). Several of the INS cells that were part of a CK 19-positive cluster were found to be CK 19-positive and gave the impression of budding off from these clusters (Fig. 3C, D). Of all INS-cells, 3\% was also positive for CK 19. 

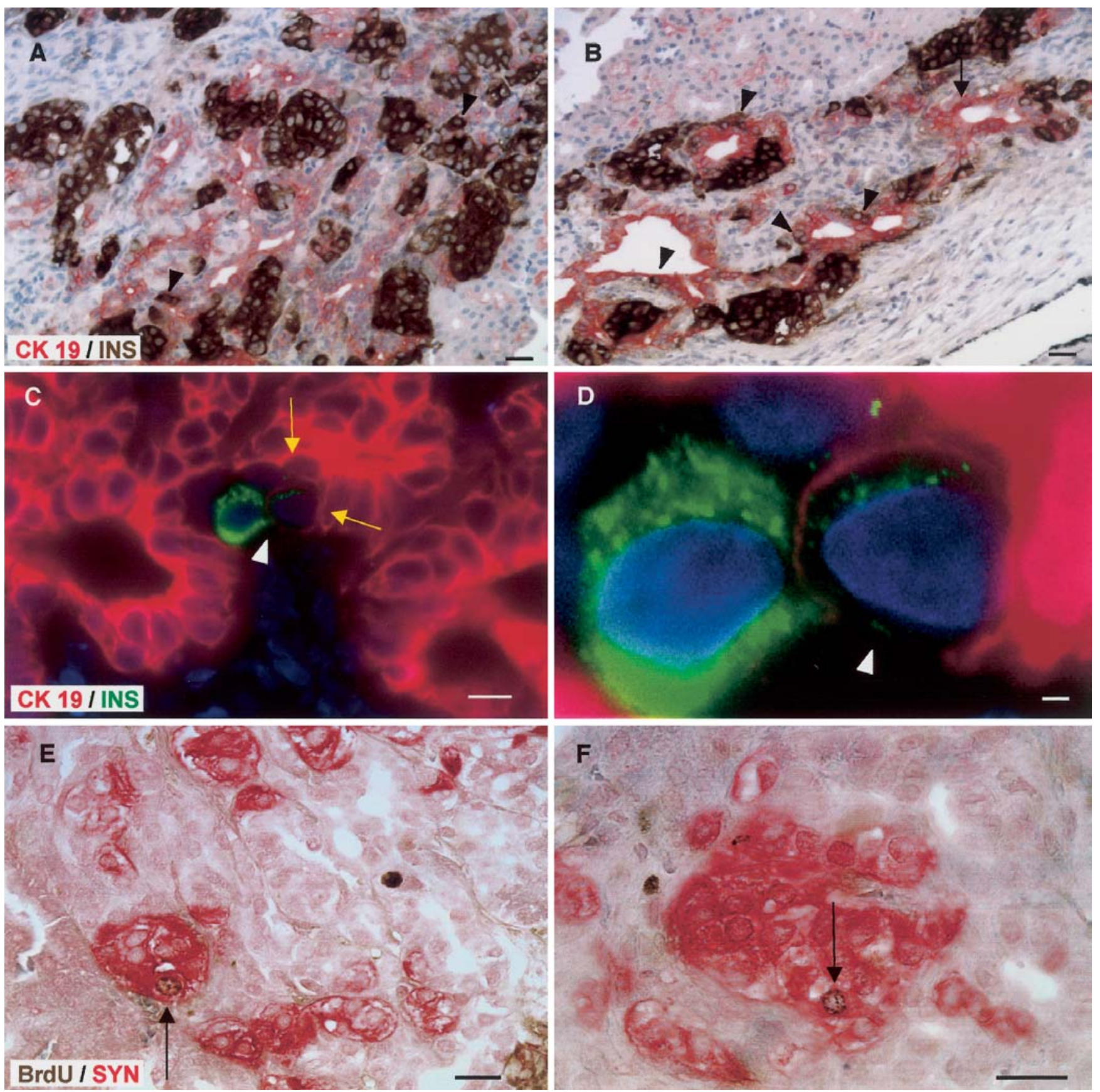

Fig. 3A-F. Double immunocytochemical staining of a human duct-cell graft from a 1-year-old donor for the duct cell marker CK 19 (red) and for insulin (brown) at 10 weeks after transplantation. CK 19-positive cells form duct-like structures (arrow) associated with numerous clusters of insulin-positive cells of different sizes. Single insulin-positive cells (arrow head) appear to be "budding" from neighboring CK 19-positive cells

(A, B) possibly indicating neoformation from existing duct cells. Cells, positive for both insulin (green) and CK19 (red) (C, D; arrowhead), are found adjacent to CK 19-positive cells (arrows) in duct-like structures. Proliferating endocrine cells (arrows), immunopositive for both BrdU (brown) and synaptophysin $(r e d)$, are present in endocrine cell clusters $(\mathbf{E}, \mathbf{F})$. The scale bars represent $20 \mu \mathrm{m}(\mathbf{A}, \mathbf{B}, \mathbf{C}, \mathbf{E}, \mathbf{F})$ and $5 \mu \mathrm{m}(\mathbf{D})$

Table 4. Presence of proliferating endocrine cells in implants 10 weeks after transplantation

\begin{tabular}{lll}
\hline Donor age (years) & Number of implants with BrdU + SYN + cells & BrdU+SYN + cells $(\%)$ \\
\hline $0-10$ & $4 / 6$ & $0.6 \pm 0.4^{*}$ \\
$>10$ & $0 / 8$ & $<1$ per 2000 \\
\hline
\end{tabular}

$*$ data are expressed as means $\pm \mathrm{SD}$ 
The endocrine cell compartment of the 10-week implants from young donors was also characterized by the presence of proliferating cells as judged by the number of SYN cells that were also positive for BrdU (Table 4). In four out of six of these implants, between one and ten double positive cells were counted per 1000 SYN-positive cells (Table 4). These double positive cells were predominantly located within endocrine cell aggregates (Fig. 3E, F). Consecutive sections showed the presence of BrdU-positive INS-positive cells $(0.3 \%$ of INS cells $)$ in similar locations. No BrdU positivity was detected in SYN cells of 10-week implants from older donors (under the detection limit of one positive cell per 2,000 cells) (Table 4).

\section{Discussion}

The postnatal pancreas is expected to maintain formation of new beta cells under normoglycaemic conditions. Several in vitro and in vivo observations have suggested that this process is achieved by, or in the vicinity of, duct cells $[18,27,28,29,30]$. We examined whether isolated postnatal human duct-cell preparations have this property when transplanted under the kidney capsule of normal mice. A duct cell-containing fraction was obtained during the islet-cell isolation procedure that is conducted for our clinical trial on beta-cell transplantation, and is further enriched during suspension culture [19, 20, 21, 22, 23]. Grafts are then prepared that contain approximately 0.5 million cells and mainly consist of CK 19 marked duct cells (80\%) with acinar cells as major contaminant (18\%); endocrine and insulin-positive cells were rare $(<2 \%)$ but consistently present. The experiment was designed to detect an increase in beta-cell mass between posttransplantation week 0.5 and 10 .

During the first week after transplantation, a large fraction of acinar cells either disappeared or changed their phenotype, as has been suggested in other models $[31,32]$. At week 0.5 , the implants consisted of more than $90 \%$ duct cells while the endocrine-cell contamination remained constant and was distributed evenly over the implant. Over the next 9 weeks, the remaining acinar cells were lost, as was $90 \%$ or more of the duct cells as indicated by volumetric analysis. The fate of the endocrine-cell volume was variable: in implants prepared from donors older than 10 years, a $65 \%$ decrease was noticed, but those from younger donors had, on average, a 2.5-fold increase. The small number of cases in this younger age category does not allow us to make further subdivisions for age. The enlarged endocrine cell compartment, as marked by synaptophysin, was composed for $72 \%$ of insulin- and for $22 \%$ of glucagon-containing cells. Its relative volume in the implant had increased from $2 \%$ at week 0.5 to $26 \%$ at week 10 . These data indicate that duct cell preparations obtained from donors under age 10 can generate new beta cells leading to a 2.5 -fold higher beta-cell mass within 9 weeks. The beta-cell mass at the end of the experiment is still small in absolute terms as it roughly corresponds to, in average, 15,000 beta cells. Our experiments were, however, not designed for a mass production of human beta cells but intended to investigate whether non-endocrine fractions that are discarded during islet isolation have a capacity for neoformation of beta cells.

The mechanisms underlying the observed increase in beta-cell mass have not been identified, but potential components can be proposed. Since beta cells at week 0.5 and week 10 showed comparable cell sizes, the increase in beta-cell mass can only be attributed to an increase in beta-cell number. Our observations are compatible with a role of duct-(associated) cells in this process but do not prove it. The neoformed endocrine-cell clusters were closely associated with duct cell-lined sacs or ductules, which has been proposed as suggestive for a role of duct-associated cells in islet development $[1,2,3,4,15,16,17]$. Insulin-positive cells seemed to be budding from the basal side of the ductal epithelium, similar to the human fetal pancreas $[13,14$, 29, 30]. Several of these duct-associated insulin cells coexpressed the CK 19 duct cell marker, which might be indicative for their immature stage or/and their transition towards an endocrine phenotype. Such insulinpositive cells with a peripheral rim of CK 19-positive filaments have also been described in the human fetal pancreas [29]. It is conceivable that these cells express the capacity of duct structures for beta-cell neogenesis. Their numbers might be distinctly higher in duct-cell preparations from young donors which could explain the observed differences in post-transplant beta-cell mass. These double-positive cells have also been identified, be it in small numbers, in adult human pancreases [33] where they could similarly contribute to beta-cell neogenesis. As we have not detected a growing betacell mass with grafts from older donors, this could be related to inadequate numbers of these cells or inadequate conditions for their formation. It is conceivable that, with the massive postnatal growth of the pancreatic organ, the percent of beta-cell precursor cells over total pancreatic cells decreases with age, and consequently their percentage in isolated duct-cell preparations.

The presence of CK 19-insulin double positive cells are not necessarily a sign of transdifferentiation from an exocrine duct cell to a beta cell [29, 33, 34] but may as well represent beta cells that differentiate from an as yet unidentified precursor cell which could be located in the vicinity of ducts. It is still unclear whether, and if so, how, these CK 19-positive insulin cells are related to the proliferating endocrine cells that were noticed in the implants with increased betacell mass. At post-transplant week 10, BrdU-positive endocrine cells were found in four out of six implants of young donor preparations, while none were detected in the eight implants from older donors. The per- 
centage of BrdU-positive synaptophysin or insulincontaining cells varied from 0.2 to $1 \%$, which is higher than the BrdU incorporation values (less than $0.2 \%$ ) in previously reported human islet implants $[35,36,37]$. These synaptophysin or insulin BrdUpositive cells were encountered in endocrine cell clusters and did not occur as isolated units along ducts. They seem not to correspond to the CK 19-positive synaptophysin or insulin cells. These observations are compatible with the view that beta-cell neogenesis from duct-(associated) cells takes place in a different tissue compartment than that which results in the proliferation of beta cells $[6,29,38]$. They support the model in which beta cells are first formed by differentiation from duct-(associated) cells, then separate from the duct structure by a process of budding, migrate to mesenchyme where they form endocrine-cell clusters that grow through replication [15].

Studies in other models and laboratories have shown that the capacity for postnatal beta-cell neogenesis decreases with age. In the normal rodent pancreas, a progressive increase in beta-cell number occurs from birth until 5 months of age, but not thereafter [39]. Rodent islet-cell regeneration can be stimulated by $90 \%$ pancreatectomy in young but not in 5- or 15-month-old animals [40]. Little information is available on beta-cell neogenesis in the postnatal human pancreas. Transplant models like the one used in this study allow to follow endocrine differentiation of nonendocrine pancreatic cells during longer periods than in current culture models where cell death or/and proliferation of non-endocrine cells is often an obstacle. A study [41] implanted human fetal pancreatic tissue into NOD/scid mice, and observed an increase in betacell mass 21 to 28 weeks after transplantation. The authors postulated that the newly formed beta cells derived from precursor cells in the duct epithelium. Another study [5] transplanted adult rat pancreatic duct epithelium under the skin of nude mice, and found only insulin-positive cells in the vicinity of ducts that were implanted with fetal mesenchyme. While the appearance of insulin-positive cells in duct cell preparations is interesting, persistent caution will be needed to distinguish newly formed from initially "contaminating" endocrine cells; it is also not known whether the presence of duct cells can affect the survival and function of neighboring islets.

Our study on human duct-cell preparations shows that duct-associated cells might contribute to beta-cell neogenesis in humans via age-dependent steps. Adjacent small endocrine-cell clusters could participate in this process which indicates that small, and sometimes overlooked, contamination of "non-endocrine" or "duct" fractions by beta cells should not be neglected as active participants in this process. The present model can be further used to dissect participating components and search conditions that increase the rate of beta-cell neogenesis.
Acknowledgements. We thank the team of the Beta Cell Bank for providing the human pancreatic exocrine cell fractions. Prof. L. Kaufman, Department of Biostatistics and Medical Informatics, Brussels Free University is acknowledged for help with the statistical analysis. The skilful technical assistance of $\mathrm{K}$. Suenens and T. Haex is highly appreciated. This study was supported by grants from the Juvenile Diabetes Research Foundation (4-2001-434) and the Belgian Fund for Scientific Research (G.0039.96, G.0375.00, G.0282.02). It was conducted within the framework of JDRF Center for Beta Cell Therapy in Europe with the collaboration of Eurotransplant Foundation (Leiden) and the Surgical Hospital at Helsinki University (Dr. K. Salmela).

\section{References}

1. Slack JM (1995) Developmental biology of the pancreas. Development 121:1569-1580

2. Jensen J, Heller RS, Funder-Nielsen T et al. (2000) Independent development of pancreatic alpha- and beta- cells from neurogenin3-expressing precursors: a role for the notch pathway in repression of premature differentiation. Diabetes 49:163-176

3. Edlund H (2002) Pancreatic organogenesis-developmental mechanisms and implications for therapy. Nat Rev Genet 3:524-532

4. Scharfmann R (2002) Control of early development of the pancreas in rodents and humans: implications of signals from the mesenchyme. Diabetologia 43:1083-1092

5. Dudek RW, Lawrence IE Jr, Hill RS, Johnson RC (1991) Induction of islet cytodifferentiation by fetal mesenchyme in adult pancreatic ductal epithelium. Diabetes 40:10411048

6. Rosenberg L (1995) In vivo cell transformation: neogenesis of beta cells from pancreatic ductal cells. Cell Transplant 4:371-383

7. Hui H, Wright C, Perfetti R (2001) Glucagon-like peptide 1 induces differentiation of islet duodenal homeobox-1-positive pancreatic ductal cells into insulin-secreting cells. Diabetes 50:785-796

8. Zhou J, Wang X, Pineyro MA, Egan JM (1999) Glucagonlike peptide 1 and exendin-4 convert pancreatic AR42 $\mathrm{J}$ cells into glucagon- and insulin-producing cells. Diabetes 48:2358-2366

9. Rooman I, Lardon J, Bouwens L (2002) Gastrin stimulates beta-cell neogenesis and increases islet mass from transdifferentiated but not from normal exocrine pancreas tissue. Diabetes 51:686-690

10. Like AA, Chick WL (1969) Mitotic division in pancreatic beta cells. Science 163:941-943

11. Swenne I (1992) Pancreatic beta-cell growth and diabetes mellitus. Diabetologia 35:193-201

12. Nielsen JH, Svensson C, Galsgaard ED, Moldrup A, Billestrup N (1999) Beta cell proliferation and growth factors. J Mol Med 77:62-66

13. Conklin J (1962) Cytogenesis of the human fetal pancreas. Am J Anat 111:181-193

14. Like AA, Orci L (1972) Embryogenesis of the human pancreatic islets: a light and electron microscopic study. Diabetes 21:511-534

15. Pictet R, Rutter WJ (1972) Development of the embryonic endocrine pancreas. In: Steiner DF, Frenkel N (eds) Handbook of physiology, Sect. 7, vol 1. American Physiological Society, William and Wilkins, Washington DC, pp 2566 
16. Peters J, Jurgensen A, Kloppel G (2000) Ontogeny, differentiation and growth of the endocrine pancreas. Virchows Arch 436:527-538

17. Bonner-Weir S, Sharma A (2002) Pancreatic stem cells. J Pathol 197:519-526

18. Bonner-Weir S, Taneja M, Weir GC et al. (2000) In vitro cultivation of human islets from expanded ductal tissue. Proc Natl Acad Sci USA 97:7999-8004

19. Ling Z, Pipeleers DG (1996) Prolonged exposure of human beta cells to elevated glucose levels results in sustained cellular activation leading to a loss of glucose regulation. J Clin Invest 98:2805-2812

20. Keymeulen B, Ling Z, Gorus FK et al. (1998) Implantation of standardized beta-cell grafts in a liver segment of IDDM patients: graft and recipients characteristics in two cases of insulin-independence under maintenance immunosuppression for prior kidney graft. Diabetologia 41:452459

21. Pipeleers D, Hoorens A, Marichal-Pipeleers M, Van de Casteele M, Bouwens L, Ling Z (2001) Role of pancreatic beta-cells in the process of beta-cell death. Diabetes 50 (Suppl 1):S52-57

22. Pavlovic D, Chen MC, Bouwens L, Eizirik DL, Pipeleers D (1999) Contribution of ductal cells to cytokine responses by human pancreatic islets. Diabetes 48:29-33

23. Heimberg H, Bouwens L, Heremans Y, Van De Casteele M, Lefebvre V, Pipeleers D (2000) Adult human pancreatic duct and islet cells exhibit similarities in expression and differences in phosphorylation and complex formation of the homeodomain protein Ipf-1. Diabetes 49:571-579

24. Wiedenmann B, Franke WW, Kuhn C, Moll R, Gould VE (1986) Synaptophysin: a marker protein for neuroendocrine cells and neoplasms. Proc Natl Acad Sci USA 83:35003504

25. Gundersen HJ (1986) Stereology of arbitrary particles. A review of unbiased number and size estimators and the presentation of some new ones, in memory of William R. Thompson. J Microsc 143:3-45

26. Skau M, Pakkenberg B, Buschard K, Bock T (2001) Linear correlation between the total islet mass and the volumeweighted mean islet volume. Diabetes 50:1763-1770

27. Herrera PL, Huarte J, Sanvito F, Meda P, Orci L, Vassalli JD (1991) Embryogenesis of the murine endocrine pancreas; early expression of pancreatic polypeptide gene. Development 113:1257-1265

28. Bonner-Weir S, Baxter LA, Schuppin GT, Smith FE (1993) A second pathway for regeneration of adult exocrine and endocrine pancreas. A possible recapitulation of embryonic development. Diabetes 42:1715-1720
29. Bouwens L, Lu WG, De Krijger R (1997) Proliferation and differentiation in the human fetal endocrine pancreas. Diabetologia 1997 40:398-404

30. Polak M, Bouchareb-Banaei L, Scharfmann R, Czernichow P (2000) Early pattern of differentiation in the human pancreas. Diabetes 49:225-232

31. Brown J, Clark WR, Molnar IG, Mullen YS (1976) Fetal pancreas transplantation for reversal of streptozotocininduced diabetes in rats. Diabetes 25:56-64

32. Rooman I, Heremans Y, Heimberg H, Bouwens L (2000) Modulation of rat pancreatic acinoductal transdifferentiation and expression of PDX-1 in vitro. Diabetologia 43:907-914

33. Bouwens L, Pipeleers DG (1998) Extra-insular beta cells associated with ductules are frequent in adult human pancreas. Diabetologia 41:629-633

34. Trivedi N, Hollister-Lock J, Lopez-Avalos MD et al. (2001) Increase in beta-cell mass in transplanted porcine neonatal pancreatic cell clusters is due to proliferation of beta-cells and differentiation of duct cells. Endocrinology 142:2115-2122

35. Davalli AM, Ogawa Y, Ricordi C, Scharp DW, BonnerWeir S, Weir GC (1995) A selective decrease in the beta cell mass of human islets transplanted into diabetic nude mice. Transplantation 59:817-820

36. Tyrberg B, Eizirik DL, Hellerstrom C, Pipeleers DG, Andersson A (1996) Human pancreatic beta-cell deoxyribonucleic acid-synthesis in islet grafts decreases with increasing organ donor age but increases in response to glucose stimulation in vitro. Endocrinology 137:5694-5699

37. Tyrberg B, Ustinov J, Otonkoski T, Andersson A (2001) Stimulated endocrine cell proliferation and differentiation in transplanted human pancreatic islets: effects of the ob gene and compensatory growth of the implantation organ. Diabetes 50:301-307

38. Bouwens L, Wang RN, De Blay E, Pipeleers DG, Kloppel G (1994) Cytokeratins as markers of ductal cell differentiation and islet neogenesis in the neonatal rat pancreas. Diabetes 43:1279-1283

39. Svenstrup K, Skau M, Pakkenberg B, Buschard K, Bock T (2002) Postnatal development of beta-cells in rats. Proposed explanatory model. APMIS 110:372-378

40. Tanigawa K, Nakamura S, Kawaguchi M, Xu G, Kin S, Tamura K (1997) Effect of aging on B-cell function and replication in rat pancreas after $90 \%$ pancreatectomy. Pancreas 15:53-59

41. Castaing M, Peault B, Basmaciogullari A, Casal I, Czernichow P, Scharfmann R (2001) Blood glucose normalization upon transplantation of human embryonic pancreas into beta-cell-deficient SCID mice. Diabetologia 44:2066-2076 